Japan Social Innovation Journal, Vol. 6, No. 1, 2016

\title{
What are Crucial Issues in Promoting an Integrated Approach for Flood Risk Management in Urban Areas?
}

\section{Mikio ISHIWATARI}

\begin{abstract}
Flooding has become a serious issue in rapidly urbanizing countries. It is widely recognized that flood damages in urban areas can be decreased by taking an integrated risk management approach. This approach, however, has not been realized easily in major cities in Asia. The purpose of this paper is to examine the crucial issues in adopting the integrated approach to developing countries. It reviews Japanese experience and lessons of managing urban flood risks, and compares these lessons with situations in developing countries. It was found that establishing coordination mechanisms among a wide range of sectors is a crucial challenge. Furthermore, the paper proposes practical methods of promoting the integrated approach for urban flood risk management in developing countries.
\end{abstract}

KEYWORDS: Urban flood, Integrated flood risk management, River basin, Official development assistance, Coordination

JEL CLASSIFICATION: F35, Q54, R58

\section{INTRODUCTION}

The impacts of urban flooding are increasing in developing countries. This can be attributed to rapid urbanization. Buildings and housings are being constructed at low-lying areas in megacities without proper planning and risk management, and the value of exposed assets is accumulating. Rainwater runoff is accelerated, and infiltration of rainwater is lost because of covering grounds by concretes. Urban flooding is closely related to a poverty issue. Urbanization has increased economic and social wealth and contributed to reduce poverty. However, the urban poor that live next to waterways in the low-lying areas severely suffer from frequent floods.

It is widely recognized that flood damages in urban areas can be decreased by taking an integrated approach (Ashley et al. 2007; Jha et al. 2012). The conventional structural measures alone cannot manage flood risks. The integrated approach includes measures of structures, non-structures, regulations on development activities, urban planning and others. This approach, however, has not been realized easily in major cities (Brown 2005; Ishiwatari 2010b; Roy et al. 2008).

The purpose of this paper is to examine what are crucial issues in adopting the integrated approach for flood risk management (FRM) in urban areas to developing countries. It reviews Japanese experience and lessons of managing urban flood risks. Japan experienced severe urban floods during high economic growth from the mid-1950s, just as developing countries currently do. The Japanese organizations concerned jointly initiated an integrated FRM approach in the late-1970s and succeeded in drastically decreasing flood damages in metropolitan areas. This paper compares Japanese lessons with current issues that developing countries face in major cities in Asia. Project

Mikio Ishiwatari is Senior Advisor in Disaster Management and Water Resource Management at Japan International Cooperation Agency. 
documents and products of development assistance agencies were reviewed, and interviews with key organizations were conducted. It was found that establishing coordination mechanisms among a wide range of sectors is a crucial in promoting the integrated approach but a major challenge as well in megacities in Asia. Furthermore, the paper proposes practical methods of promoting the integrated approach in developing countries.

\section{INTEGRATED APPROACH FOR FLOOD RISK MANAGEMENT}

Recent studies and reports have proposed integrated approaches to manage flood risks in the urban areas. These studies have mainly examined the approaches and some efforts but have not evaluated actual projects completed.

The integrated approaches include a wide range of measures, such as structural, non-structural, spatial, and organizational measures (Associated Programme on Flood Management 2008). A guidebook of the World Bank defines the integrated approach to urban FRM as combination between structural and nonstructural measures. Structural measures range from hard-engineered structures to natural measures, such as wetlands and natural buffers; and non-structural measures cover warning and evacuation, preparedness, land use plan, and recovery (Jha et al. 2012). The Japanese Ministry of Land, Infrastructure, Transport and Tourism (MLIT) defines the approach as combination among (i) river improvement, (ii) river basin measures, and (iii) damage mitigation measures (MLIT 2004).

While conventional approaches of FRM cover mainly scientific and engineering issues, issues of societal exposure and vulnerability to flooding should be examined (Brown 2002). Also, FRM must be considered at different spatial scales: (i) the river and water catchment as a whole, (ii) city scale, (iii) community scale, and (iv) individual building scale (Jha et al. 2012). Consistent institutional, legislative, economic, and social arrangements are needed to apply across the entire river catchment (Roy et al. 2008).

Organizational arrangement is a crucial issue in promoting the integrated approaches. Organizations involved in urban FRM are often fragmented; and their mandates, policies, or activities are not well coordinated. Proactive disaster management requires participation from various organizations of governments, nongovernment, private sectors, and local communities (Tingsanchali, 2012). Urban offices should formulate urban plans by considering flood risks, housing offices should regulate house construction in risk areas, and disaster risk management (DRM) offices are in charge of nonstructural measures, such as evacuation and response. In addition to the government organizations, various organizations have initiated DRM activities. For example, the private sector that plays crucial roles in reducing urban disaster risks is expanding DRM activities in Japan (Aota et al. 2008). University classrooms are linked with local communities, and universities supported the communities to strengthen capacities of flood disaster management in the Philippines (Sescon 2012). Limited capacity of planning and implementations is a challenge (Brown 2005). Organizational capacities should be enhanced to implement the integrated approach for urban FRM (Hall et al. 2003).

Since the integrated FRM is useful as preparedness for low-frequent and high-impact floods, some countries have proposed this approach as adaptation approaches to climate change (Institute for Water Resources 2011; Ishiwatari 2010a). The Panel of Infrastructure of the Japanese Government issued a policy report on climate change adaptation in 2008. The panel proposed multilayered measures at river basin level, which consist of non-structural measures including community-based disaster management, land use regulation, and inundation management in floodplains in addition to structural measures. The Netherlands government takes a three layered approach in a new policy: (i) levee system reinforcements or 'room-for-river'-measures, (ii) sustainable spatial planning, and (iii) improved emergency response to floods. A report prepared by muli-agencies in USA argues that adaptation operations should include operational, demand management, and infrastructure changes. 


\section{JAPANESE EXPERIENCE}

This section reviews how Japan could apply the integrated approach to urban FRM and decrease flood damages, and lessons from its experience.

\subsection{How Serious was Urban Flooding in Japan?}

Increasing flood damages in urban areas became a serious social issue during high economic growth from the mid-1950s in Japan. While urbanization contributed to economic growth that was critical to poverty reduction, urban development increased flood risks in the Tokyo, Osaka, and Nagoya metropolitan areas. Large-scale housing development in hill areas reduced infiltration of rainfall water into the ground and accelerated runoff to rivers. Paddy fields, which used to serve as flood retardation ponds, were converted into residential areas. These development activities increased flood frequency and intensity, leading to damage growth in downstream low-lying areas. Also, urban development in flood-prone areas increased the value of exposed assets. The movement of people from rural to urban areas contributed to the high growth of these metropolitan areas (Musiake, 2012). In this period 300-400,000 people migrated to the Tokyo metropolitan area every year, 100-200,000 people migrated to the Oskaka metropolitan area, and some 50,000 people migrated to the Nagoya metropolitan area.

\subsection{What Approach did Japan Initiate?}

The Japanese Government initiated the new approach of urban FRM in 1977. The conventional engineering-oriented approach alone could not resolve the serious flooding caused by rapid urbanization. Organizations concerned started promoting measures in the whole river basins outside the river channels. This is regarded as the paradigm shift of Japanese FRM: 'from channel to basin' (Kundzewicz et al. 1999). Japan had implemented structural measures, such as dykes and reservoirs, inside river channels for the last one century by employing modern technology that was introduced from the Netherland and other Western countries. Flood water is collected into rivers and allowed to flow out into the sea as quickly as possible (Takahashi and Uitto 2004).

Investments in the urban FRM paid off. Flood damages had substantially decreased in the urban areas because of the integrated approach. The Japanese government invested 3.7 trillion JPY, some 30 billion USD, in 17 urban rivers selected in the Tokyo, Osaka, and Nagoya metropolitan areas. Budgets allocated for these rivers have been twice as large as the average for other rivers in the country. It is estimated that damage of 12.7 trillion JPY, 105 billion USD, was avoided. The government estimates an actual benefit-cost ratio for the total investment at 3.4 (MLIT 2004).

The integrated approach consisted of (i) river improvement works, (ii) measures distributed in the river basins, and (iii) nonstructural measures as follows:

(i) River improvement works: These are conventional structural works, such as channel improvement, reservoirs, and diversion channels. The river management offices of national and prefectural governments implement these works.

(ii) River basin measures: These measures were newly introduced to FRM. Various facilities are constructed in the whole river basins to increase rainfall infiltration and storage capacities. Prefectural and municipality governments implement the following measures.

a. Upper stream area: The capacity of retarding floods is increased to reduce flood runoff to the lower stream. Since it is difficult to acquire lands for ponds or reservoirs in densely developed urban areas, multifunctional facilities are developed. Lands owned by the municipality 
governments, such as school grounds and sports facilities, are used for retarding ponds in case of flooding. Private companies must construct the retarding ponds to offset run-off volume increased by residential development. Rainfall infiltration facilities and permeable pavements are also installed.

b. Middle stream area: Inundation is accepted in this area to reduce flood discharge to downstream areas. The municipality governments identify preservation zones for agricultural and natural lands and regulate land use. Also, the governments control development activities, such as landfill, not to increase flood discharge.

c. Downstream area: The area is densely populated and vulnerable to inundation. To mitigate inundation damages flood water is stored in retarding ponds and sewerage facilities. The municipality governments encourage residents to construct raised floor houses to avoid inundation.

(iii) Nonstructural measures: The river management offices and municipality governments support local communities to respond to flooding. The local governments distribute hazard maps to residents, and government organizations issue early warning. The communities use disaster information for evacuation.

Flood fighting organizations, "suibo-dan" in Japanese, play an important role in managing flooding through the history of Japan. These organizations are formed on community-based and emerged in the middle and early modern periods to protect their own communities from floods. The organization members engage in patrolling, assisting evacuation, warning, and operating gates as well as flood fighting by reinforcing embankments and piling sandbags during flooding. Some 900,000 members belong to the organizations nationwide (Ishiwatari 2012). National and local governments provide financial support to suibo-dan.

Japan is still suffering from urban floods. While inundation areas and the number of inundated houses have been decreased, damage costs have increased because of accumulating assets in urban areas. There are some issues: 1) insufficient facilities, 2) discrepancies between predicted and actual land use, 3) deterioration or reclamation of retarding facilities because of unclear legal status, and 4) new type of flood damage, such as flooding of basement spaces. "Act on Countermeasures against Flood Damage of Specified Urban Rivers" was enacted in 2004. This act aims to enhance the integrated approach in urban areas. It prescribes development of FRM plans at the river basin level, construction of rainwater storage and infiltration facilities by river management offices, regulation of development, designation of risk areas, etc.

\subsection{What are Coordination Mechanisms?}

The coordination is the key to effectively promote countermeasures distributed in the river basins. River basin committees were established as the coordinating body among governmental offices (figure 1). The committee members examine and finalize master plans, action plans, and other related plans at committee meetings. The river offices of the national and prefecture governments play the leading role in organizing the committees as the secretariats and draft FRM master plans from a river basin perspective. The committees usually consist of the following offices:

- Urban planning: to formulate urban plans, to regulate land use, and to require private companies to offset rainfall runoff increased by development activities

- Housing: to support housing owners to construct raised floor houses and on-site infiltration facilities

- $\quad$ Sewerage: to construct restoring facilities in sewerage systems

- Land management and agricultural land: to control development activities at agricultural lands and preserved areas 
Japan Social Innovation Journal, Vol. 6, No. 1, 2016

- $\quad$ Road: to construct permeable pavements on roads

The master plans serve as the basis for coordinating roles of the concerned offices. Rainfall-runoff processes are simulated at the river basin scale, and the targeted flood volume was determined. This flood volume is allocated to structural measures including river channels, reservoirs, and river basin measures. The planning process is supported by scientific analysis, hydro-metrological data and geographical surveys.

Figure 1: Concept of coordinating mechanism

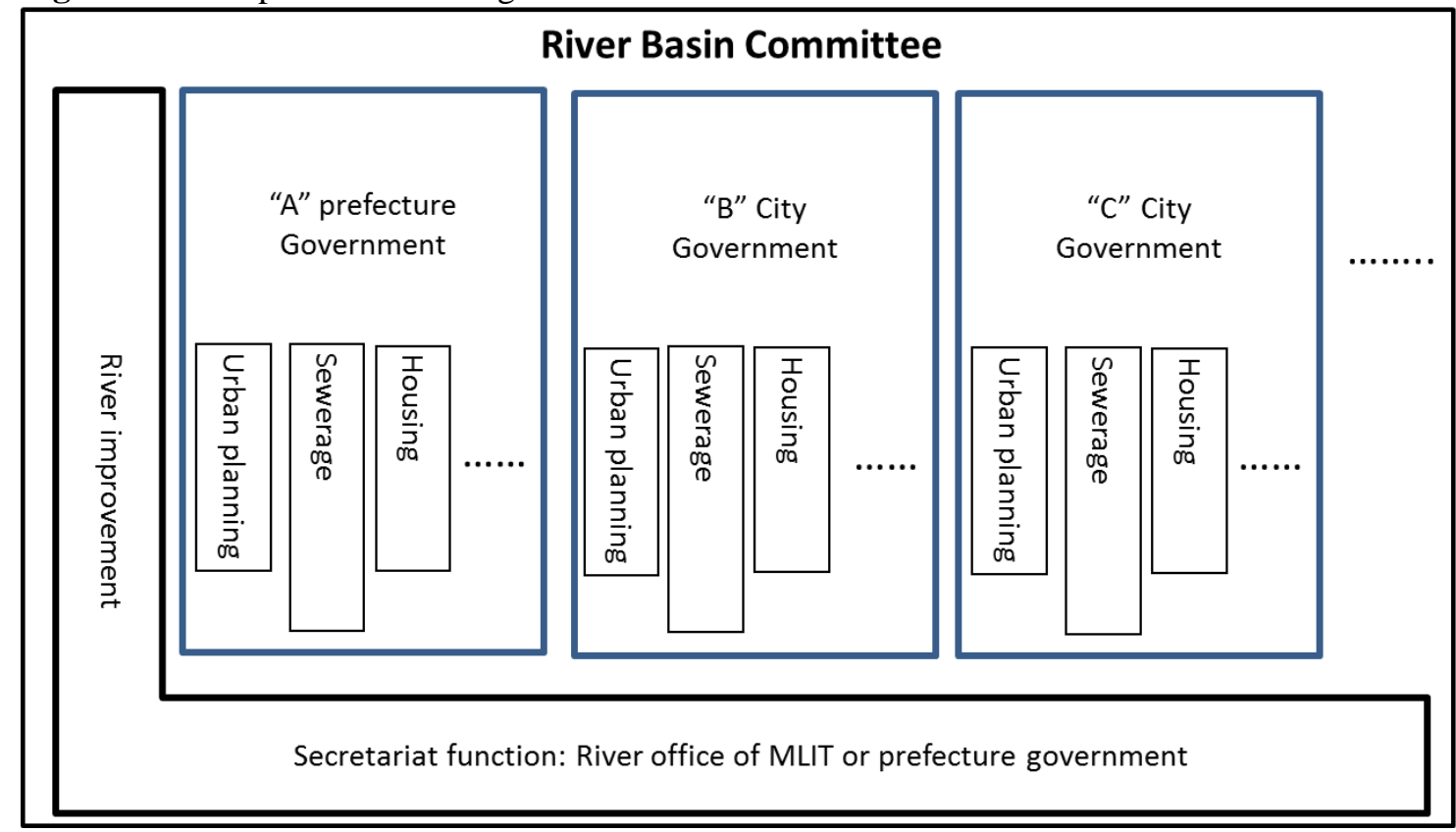

Source: Author's survey

The municipality governments require private companies to construct retarding ponds not to worsen flooding because of residential development and formulated guidelines for facilities. For example, the private companies are required to construct the ponds with capacities from $300 \mathrm{~m}^{3}$ to $600 \mathrm{~m}^{3}$ per $1,000 \mathrm{~m}^{2}$ of house-land development. The housing offices of the governments approve construction plans of the private companies, and inspect their works.

While the coordination mechanisms are established, there still remain some issues. It is difficult to coordinate construction of the retarding ponds at schools and parks with these administrators in some river basins. Most municipality governments faced fiscal difficulties and cannot allocate enough budgets for park and school maintenance.

The municipality governments do not have guided small-scale residential development. The guidelines cover large-scale development but do not cover small-scale development or individual house construction. Also, there are limited cases of construction of raised floor houses and on-site infiltration facilities. While the municipality governments provide financial support to house owners, the owners have to share some amount of construction costs. The governments have prioritized civil works, and regulation on large-scale development.

\subsection{Case of Tsurumigawa River Basin}

This section explains the details of countermeasures implemented in the Tsurumigawa river basin, where the integrated approach evolved on the ground. The Tsurumigawa river basin is located in the Tokyo metropolitan area and has been developed as 'bedroom towns', satellite towns for commuters 
to the central Tokyo. The urban area expanded from 10\% of the river basin area in 1958 to $85 \%$ in 2003. The flood peak volume of the river had more than doubled because of rapid urban development during this period (Keihin River Office Website, undated). Accordingly, people had suffered from severe floods in the 1960s and 70s.

The river basin committee, which consisted of vice-governors of Tokyo and Kanagawa prefectures, three vice-mayors, and Kanto Regional Director General of MLIT, was established to formulate the master plan and to implement the FRM measures in the plan. The committee could decide policy issues on FRM, since these committee members had high authority in their organizations. The working group consisting of these organizations coordinated measures to be implemented.

The committee formulated the master plan of the integrated FRM at the river basin level in 1981 as the first plan in Japan. The plan aimed to upgrade flood safety and to maintain and strengthen retarding function in the whole river basin. Urbanization, however, had proceeded at an unexpected pace. The committee revised the plan in 1989 and revised it again in 2008. The most recent plan aims to strengthen collaboration with sewerage offices and civil society organizations.

Based on the master plans, organizations concerned have implemented countermeasures. Flood damages drastically decreased as shown in Figure 2.

Figure 2: Number of Inundated houses

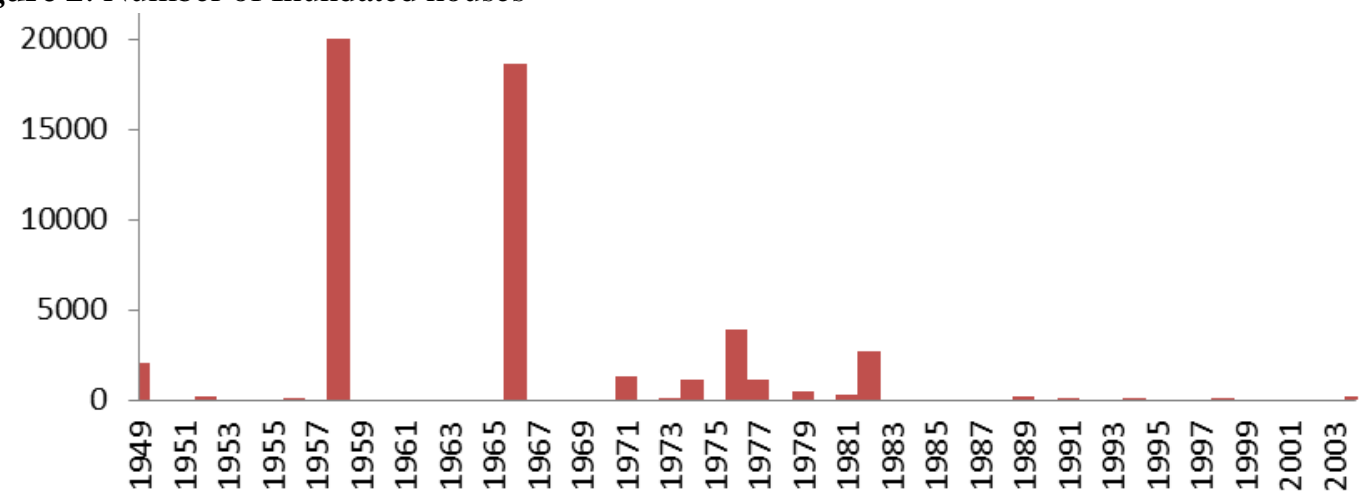

Source: Keihin River Office Website.

The river office of the national government constructed the Tsurumigawa multi-purpose reservoir, which has the restoring capacity of 3.9 million $\mathrm{m}^{3}$ and reduces the peak flood volume of the Tsurumigawa River by $300 \mathrm{~m}^{3} / \mathrm{s}$. The Yokohana city government constructed the Yokohama Stadium, the largest sport stadium in the country, and other public facilities at the multi-purpose reservoir area.

Private companies constructed retarding ponds with the total capacity of 1.3 million $\mathrm{m}^{3}$, and other organizations have constructed retarding ponds with the capacities of 1.4 million $\mathrm{m}^{3}$. They have constructed some 3,300 ponds to offset flood volumes increased by development activities in urban areas (Unno 2003).

The local governments distributed disaster management maps to local communities at the normal times. The maps indicate risk areas, inundation depths predicted, evacuation routes and centers, and other information useful for evacuation. The local communities can access information on river water levels and rainfall volume on the web at the time of flooding.

\subsection{Lessons from Japanese Experience}

The following lessons can be learned from Japanese experiences. 
Japan Social Innovation Journal, Vol. 6, No. 1, 2016

a) The integrated approach can substantially decrease flood damages. Investment in the integrated approach paid off. Conventional structural measures alone cannot resolve issues of urban flooding. Local governments constructed rainfall retarding and infiltration facilities in the whole river basin in relatively shorter periods than constructing channel works.

b) "Prevention is better than cure" in urban FRM as is the case in risk management of other disasters. Proactive management by urban planning and regulation are required to guide balanced development. It is quite difficult to implement structural measures, once urban areas are highly utilized. Land acquisition and relocation for channel works need complicated processes and long periods. Japan is currently forced to construct underground structures with enormous budgets in urban areas, which are extremely developed. However, a government guideline discourages constructing the underground channels from operation and maintenance perspectives (Japan Institute of Country-ology and Engineering 2005).

c) Budget and technology are not serious issues to promote the integrated approach. The countermeasures, such as retarding ponds and infiltration facilities, need low-cost technology and simple works only. High-technology is not applied to most measures.

d) Establishing robust coordination mechanisms is the key to conduct measures in the river basins. Various organizations had to be involved in implementing the measures. Private companies conduct most development activities in the urban areas. Municipality governments required the companies to implement the measures according to guidelines for residential development.

e) The master plans serve as the bases for sharing responsibilities among the organizations concerned. The plans could clarify measures that each organization should implement. The river basin is a suitable planning unit for FRM. Within the river basin, experts could analyze and quantify a hydrologic process and propose action plans. These plans were formulated based on scientific analysis and accumulated data and have been revised as land use changed.

\section{FLOOD RISK MANAGEMENT IN LARGE CITIES IN ASIA}

Urbanization has increased vulnerability to flooding in Asian cities as the Japanese megacities experienced during the high economic growth. For example, Bangkok and Manila suffered from unprecedented scale of flooding in 2011 and 2009 respectively. Budiyono et al. (2015) estimates annual expected damages by flooding in Ho Chi Minh City (HCMC), Manila and Jakarta at 191 million USD, 114 million USD, and 321 million USD respectively. Structural measures of drainage systems, pumping stations, and channel improvement have been poorly developed in built-up urban areas. Unregulated construction, solid waste management, and land subsidence have exacerbated flooding.

Major development assistance agencies, such as Japan International Cooperation Agency (JICA) and the World Bank, have conducted FRM projects in megacities including Manila, Ho Chi Minh City, and Jakarta. These cities started introducing integrated FRM approaches as Japan adopted to decrease floods in megacities. This section reviews the projects, and examines barriers to realizing the integrated approaches on the ground.

\subsection{Manila}

Urban poor have severely suffered from flooding in Metro Manila. Informal settlements at risk from coastal flooding account for 35 per cent of the population in Metro Manila (UN-HABITAT 2007). Typhoon Ondoy inundated an area of at least of 20\% of Metro Manila in 2009 (Chiplunkar et al. 2012). Muto et al. (2010) predicts that flood damage at the scale of once-in-one-hundred-year would increase by 60-70 percent in 2050 because of climate change. 
Japan Social Innovation Journal, Vol. 6, No. 1, 2016

JICA has supported the Philippines to implement structural measures of improving river channels, installing pumping stations, and developing early warning systems in Metro Manila from the 1970s. These facilities have contributed to substantially decrease flood damages. For example, Manggahan Floodway constructed in 1986 decreased flood damages by Typhoon Ondoy in the city center. Floodwater was diverted from the main channel of Pasig-Marikina River to Laguna Lake and stored for a few days.

JICA supported to formulate the master plan of FRM in Cavite Province, which is located next to Metro Manila and experiencing rapid urbanization (Ishiwatari 2009). The master plan proposes various measures, such as urban planning and retarding basins in flood plains, in addition to the conventional works of channel improvement. While the works of channel improvement started, the provincial government has not developed nonstructural measures yet.

Many agencies, including national government organizations and local government units, are involved in FRM in Metro Manila. Coordinating these organizations is not functioning well. The institutional arrangement is very fragmented, and mandates of the organizations are overlapped (The World Bank, 2014).

\subsection{Ho Chi Minh City}

The majority of the urbanized area is located at two to three meters above sea level, and the city has suffered from flooding frequently. Asian Development Bank (2010) predicts that inundation areas would increase from 54\% to $61 \%$ in 2050 for regular flooding and that average maximum flood depth would increase by $21 \%$.

JICA supported HCMC to formulate the FRM master plan (JICA 1999). Based on the master plan the city has improved channels to increase flood flow capacity under the support of development assistance agencies. However, the city hardly constructed retarding ponds, or regulated land use that the JICA master plan recommends.

Institutions and legal frameworks should be improved to introduce the integrated approach in HCMC (Nugyen et al. 2014). HCMC established a specialized office for flood management, Steering Center for Urban Flood Control. This new office needs to develop capacity. The World Bank (2015) points out that this office has limited capacity in coordination among various organizations, planning FRM, and conducting emergency response.

\subsection{Jakarta}

Jakarta has suffered devastating floods almost once in five years: in 1997, 2002, 2007, and 2013. These floods had great impacts on the country. Flooding in 2007 inundated some $45 \%$ of the Jakarta Metropolitan area. Flood water flowed into the central area of Jakarta in 2013 and submerged embassies and the presidential palace.

Rapid urbanization would aggravate flood damages. JICA (2013) predicts that the flood peak discharge of 50-year return period would increase from $480 \mathrm{~m}^{3} / \mathrm{s}$ in 2008 to $720 \mathrm{~m}^{3} / \mathrm{s}$ in 2030 because of urbanization. Also, land subsidence, which has been advancing because of intensive deep groundwater abstraction, is increasing risks of tidal floods.

JICA supported to formulate a FRM master plan in Jakarta. The master plan recommends the integrated approach in line with the Japanese approach: (1) river channel improvement, (2) runoff facilities in river basins, (3) land use regulation, and (4) disaster mitigation measures. The World Bank (2012) stresses that inter-agency coordination should be strengthened and that capacity, personnel, and funding should be improved. 
Japan Social Innovation Journal, Vol. 6, No. 1, 2016

\subsection{Institutional Arrangement}

Three cities face the same challenges of limited institutional capacities and fragmented organizational arrangements (Table 1). Multiple national and local government agencies are in charge of structural works. Various offices inside local governments were involved in disaster risk management (DRM), and urban planning in metropolitan areas. In case of Manila some 20 local governments are in charge of DRM and urban planning. Sharing disaster information issued by the national government agencies with many local governments is a challenge.

Table 1: Key organizations of Flood risk management in three cities

\begin{tabular}{|l|l|l|l|}
\hline countermeasures & Manila & HCMC & Jakarta \\
\hline $\begin{array}{l}\text { Flood } \\
\text { management of rivers }\end{array}$ & public work ministry & $\begin{array}{l}\text { agriculture and rural } \\
\text { development ministry }\end{array}$ & public work ministry \\
\hline $\begin{array}{l}\text { Flood } \\
\text { management of } \\
\text { channels in cities }\end{array}$ & $\begin{array}{l}\text { regional development } \\
\text { ministry } \\
16 \text { cities } \\
\text { one town } \\
4 \text { provinces }\end{array}$ & $\begin{array}{l}\text { city government } \\
\text { province government }\end{array}$ & $\begin{array}{l}\text { province governments } \\
\text { city governments }\end{array}$ \\
\hline $\begin{array}{l}\text { Flood forecasting } \\
\text { \& warning }\end{array}$ & $\begin{array}{l}\text { Hydro-meteorological } \\
\text { agency }\end{array}$ & $\begin{array}{l}\text { Hydro-meteorological } \\
\text { agency }\end{array}$ & public work ministry \\
\hline DRM & $\begin{array}{l}16 \text { cities } \\
\text { one town } \\
\text { 4 provinces }\end{array}$ & $\begin{array}{l}\text { city government } \\
\text { province government }\end{array}$ & $\begin{array}{l}\text { province governments } \\
\text { city governments }\end{array}$ \\
\hline Urban Planning & $\begin{array}{l}16 \text { cities } \\
\text { one town } \\
4 \text { provinces }\end{array}$ & $\begin{array}{l}\text { city government } \\
\text { province government }\end{array}$ & $\begin{array}{l}\text { province governments } \\
\text { city governments }\end{array}$ \\
\hline Source: Author's survey & \multicolumn{2}{|l}{} \\
\hline
\end{tabular}

\section{CONCLUSION}

The Japanese case shows that the integrated approach for FRM can substantially decrease flood damages in urban areas. This approach covers (i) river improvement works; (ii) basin measures, which are distributed in the whole river basins; and (iii) nonstructural measures. It was found that a wide range of sectors, such as DRM, urban, water, and sewerage, should be involved in FRM. Also, the private sector should be engaged in implementing countermeasures in the river basins. Coordinating mechanisms among a wide range of offices and sectors are needed to effectively promote various counter measures in the whole river basins. Since simple works are required for implementing measures in the river basins, technical or engineering issues are not crucial in promoting the integrated approaches.

Manila, Ho Chi Minh City, and Jakarta have suffered from severe flooding and had promoted FRM under the support of development assistance agencies. These cities are facing the same issue of limited capacity in coordination and planning to implement the integrated approach. Institutional arrangements are complex, since various organizations are involved in FRM at national and local levels. This is the most crucial barrier to promote the integrated approach. As Japanese case shows, these cities should establish coordinating frameworks.

\section{CONSIDERATION}

The development assistance agencies should prioritize capacity development of local governments to promote the integrated approach for FRM in urban areas. Currently these agencies are mainly 
providing developing countries with financial support to implement structural measures and technical support in engineering issues. The capacity development programs should include institutional arrangement, legislation development, and staff capacity building. Establishing coordinating bodies need legislation and budget mechanisms. These bodies require high authority in the government to lead coordination among various organizations. The secretariat offices of the coordinating bodies are expected to formulate master plans that provide the basis for sharing responsibilities among organizations concerned. Also, budgetary systems, which make clear budget sharing among the organizations concerned, should be established.

The development assistance agencies should support developing countries to implement proactive approaches of managing urban development from a FRM perspective. Once city centers are highly urbanized, it becomes difficult to acquire lands for widening river channels. The local governments need to manage land use to avoid inappropriate development in risk areas and to manage flood risks.

\section{REFERENCES}

Aota, R. Hokugo A., Murosaki M. (2008). Urban disaster reduction in the private sector: Based on the lessons from past disasters, Report of Research Center for Urban Safety and Security Kobe University 12 (in Japanese).

Ashley, R. M., Blanksby, J., Chapman, J., Zhou, J. (2007). Towards integrated approaches to reduce flood risk in urban areas. Advances in Urban Flood Management, 415-432.

Asian Development Bank. (2010). Ho Chi Minh City adaption to climate change, Mandaluyong City: Asian Development Bank.

Associated Programme on Flood Management. (2008). Urban Flood Risk Management: A Tool for Integrated Flood Management, Geneva: World Metrological Organization.

Brown, J. D., Damery, S. L. (2002). Managing flood risk in the UK: towards an integration of social and technical perspectives. Transactions of the Institute of British Geographers, 27(4), 412-426.

Brown, R. R. (2005). Impediments to integrated urban stormwater management: the need for institutional reform. Environmental management, 36(3), 455-468.

Budiyono, Y., Aerts, J., Brinkman, J., Marfai, M. A., Ward, P. (2015). Flood risk assessment for delta mega-cities: a case study of Jakarta. Natural hazards, 75(1), 389-413.

Chiplunkar, A., Seetharam, K., Tan, C. K. (2012). Good practices in urban water management. Mandaluyong: Asian Development Bank.

Hall, J. W., Meadowcroft, I. C., Sayers, P. B., Bramley, M. E. (2003). Integrated flood risk management in England and Wales. Natural Hazards Review, 4(3), 126-135.

Ho L. P, et al. (2014). Integrated urban flood risk management approach in context of uncertainties: case study Ho Chi Minh city, La Houille Blanche, 6, 26-33.

Institute for Water Resources. (2011). Flood risk management approaches: As being practiced in Japan, Netherlands, United Kingdom and United States, IWT Report R-08, IWR, Washington DC: US Army of Corps of Engineers.

Ishiwatari, M. (2009). Climate Change Adaptation in Urban Floods: Case Study in Suburb of Metro Manila, In Proc. World City Water Forum 2009, 803-810, Inchon. 
Institute for Policy Analysis and Social Innovation, University of Hyogo

Published online: March 31, 2016

Japan Social Innovation Journal, Vol. 6, No. 1, 2016

Ishiwatari, M. (2010a). Integrated management of urban flooding for climate change adaptation in developing countries. In R. Shaw, J. M. Pulhin, J. J. Pereira (Ed.), Climate Change Adaptation and Disaster Risk Reduction: Issues and Challenges Community, Environment and Disaster Risk Management 4, 305-323.

Ishiwatari, M. (2010b). Shifting paradigm of Japanese Assistance in disaster risk management in the Philippines, In Proc. 5th Civil Engineering Conference in the Asian Region and Australasian Structural Engineering Conference 2010. 625-630, Sydney.

Ishiwatari, M. (2012). Government roles in community-based disaster risk reduction. In R. Shaw (Ed.), Community-Based Disaster Risk Reduction: Community, Environment and Disaster Risk Management 10, 19-33.

Jha, A. K., Bloch, R., Lamond, J. (2012). Cities and flooding: a guide to integrated urban flood risk management for the 21st century. The World Bank, Washington DC.

Japan Institute of Country-ology and Engineering (2005). Guidelines for urban river planning: underground river planning (in Japanese), Tokyo: Sankaido.

Japan International Cooperation Agency (JICA). (2013). The project for capacity development of Jakarta comprehensive flood management in Indonesia, Tokyo: JICA.

JICA. (1999). The study on urban drainage and sewerage system for Ho Chi Minh City in the Socialist Republic of Viet Nam, Tokyo: JICA.

Keihin River Office Website. (in Japanese) http://www.ktr.mlit.go.jp/keihin/

Kundzewicz W., Takeuchi K. (1999). Flood protection and management: quo vadimus?, Hydrological Sciences Journal, 44(3), 417-432.

Ministry of Land, Infrastructure, Transport and Tourism (MLIT) (2004). Program evaluation on integrated flood management with river basin (in Japanese) Tokyo: MLIT.

Musiake, K. (2012). Japan's experiences in urban flood disaster mitigation measures and urban watershed management. IWP Working Paper LKYSPP 12-10.

Muto, M., Morishita, K., and Syson, L. (2010). Impacts of Climate Change upon Asian Coastal Areas: The case of Metro Manila, Tokyo: JICA.

Roy, A. H., Wenger, S. J., Fletcher, T. D., Walsh, C. J., Ladson, A. R., Shuster, W. D., Brown, R. R. (2008). Impediments and solutions to sustainable, watershed-scale urban stormwater management: lessons from Australia and the United States. Environmental management, 42(2), 344-359.

Sescon, J., Tuano, P. (2012). Service learning as a response to disasters and social development: A Philippine experience, Japan Social Innovation Journal, 2(1).

Takahasi, Y., \& Uitto, J. I. (2004). Evolution of river management in Japan: from focus on economic benefits to a comprehensive view. Global Environmental Change, 14, 63-70.

Tingsanchali, T. (2012). Urban flood disaster management. Procedia engineering, 32, 25-37.

UN-HABITAT (2007). Global report on human settlements 2007 - Enhancing Urban Safety and Security, Nairobi: UN-HABITAT. 
Institute for Policy Analysis and Social Innovation, University of Hyogo

Published online: March 31, 2016

Japan Social Innovation Journal, Vol. 6, No. 1, 2016

Unno S. (2003). Comprehensive water management in Japan, Presentation at the Third World Water Forum, Kyoto.

World Bank. (2012). Project appraisal document, Jakarta urgent flood mitigation project (Jakarta emergency dredging initiative), Washington, DC: The World Bank.

World Bank. (2014). Project information document- preparation of a program towards sustainable flood management in the Greater Metro Manila Area, Washington, DC: The World Bank.

World Bank. (2015). Project information document- HCMC flood risk management, Washington, DC: The World Bank.

Open Access Article. This work is licensed under a Creative Commons Attribution-NonCommercial 3.0 Unported License. To view a copy of this license, visit http://creativecommons.org/licenses/by-nc/3.0/.

\section{Publisher:}

Institute for Policy Analysis and Social Innovation, University of Hyogo 